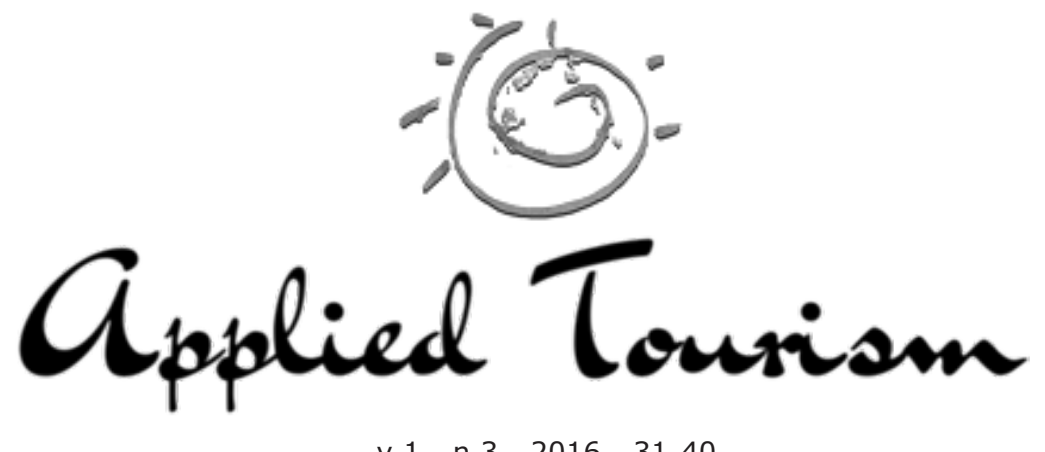

v. $1-n .3-2016-31-40$

\title{
CARACTERIZAÇÃO DE FOOD TRUCKS PRESENTES EM EVENTOS GASTRONÔMICOS NO MUNICÍPIO DO RIO DE JANEIRO
}

\section{CHARACTERIZATION OF FOOD TRUCKS IN GASTRONOMIC EVENTS IN THE CITY OF RIO DE JANEIRO}

\author{
Elga Batista da Silva - Doutoranda em Ciência e Tecnologia \\ de Alimentos UFRRJ - elga.silva@hotmail.com \\ Flávio Henrique Gomes Borges - Graduando do curso de \\ Hotelaria UFRRJ - borges_hotelaria@yahoo.com.br \\ Andressa Menezes Souza - Mestre em Divulgação \\ Científica e Cultural IFRJ - \\ andressamsouza@hotmail.com \\ Andrea dos Anjos Silva - Doutoranda em Ciência e \\ Tecnologia de Alimentos UFRRJ - anjos.nutri@gmail.com \\ Recebido/Received: 08/08/2016 - Aprovação/Approval: 12/12/2016
}

RESUMO: Eventos de food truck têm acontecido em vários locais do Rio de Janeiro, nos quais encontram-se tantos pratos internacionais famosos quanto comidas locais, além de cervejas gourmet. Essa pesquisa caracterizou food trucks no Rio de Janeiro, sendo para tanto realizado um estudo em cinco eventos gastronômicos desse tipo, selecionando em cada evento 10 empresas. Foi observada uma maior presença de caminhões do que food bikes e carrocinhas. Percebeu-se ser comum nesses eventos a baixa presença de propagandas; e poucos funcionários, estes receptivos e comprometidos um atendimento baseado na hospitalidade. Sobre os perfis dos cardápios, houve predominância de itens da Cozinha Norte Americana, seguida da Italiana; e muitas opções de sanduíches diversos. Um ponto negativo nesses eventos é o fator
ABSTRACT: Food truck events have taken place in various locations in the city of Rio de Janeiro, Brazil, where there are many famous international dishes as local foods and gourmet beers. This research charactherized food trucks in Rio de Janeiro, and to both a study in five gastronomic events of this type, selecting 10 companies in each event. A greater presence of trucks than food carts and bikes was observed. It was perceived to be common in these events the low presence of advertisements and a small quantity of employees. Though in reduced number, the employees were receptive and committed, a service based on hospitality. On the menus' profiles, there was a predominance of items from the North American Cuisine, followed by Italian and lots of different sandwiches. One negative aspect of these events is the hygiene factor, as simple measures of this subject were not answered.

Keywords: gastronomic event; menus; street food 
higiene, pois medidas simples desse quesito não foram atendidas.

Palavras-chave: cardápios; evento gastronômico; street food

\section{INTRODUÇÃO}

O estudo de festivais e eventos gastronômicos é uma importante área do turismo cuja produção cientifica tem apresentado considerável crescimentos nas décadas recentes. Esses eventos oferecem uma oportunidade ideal para turistas e moradores locais interagirem e vivenciarem novas experiências alimentares (Bortnowska, Alberton, Marinho, 2012), o que representa uma troca cultural de relevante riqueza para os dois elementos envolvidos.

$\mathrm{Na}$ atualidade vem ocorrendo, especialmente em grandes cidades, muitos eventos tendo como tema os food trucks, outros veículos e barraquinhas, espaços nos quais é possível consumir alimentos e bebidas de diferentes cardápios com preços geralmente mais atrativos daqueles encontrados em restaurantes e serviços de alimentação em geral. Esses preços mais baratos podem ser praticados em função das características inerentes a essa proposta de serviço de alimentação, constituído por uma estrutura física simples e restrita.

Acredita-se que os food trucks surgiram em 1872, em Providence, Rhode Island, Estados Unidos, cujo dono era Walter Scott, vendedor ambulante de tortas e sanduíches destinados aos trabalhadores de fábricas, que precisavam de comida barata e rápida, fato que tornava esses alimentos boas opções. No final da década seguinte, Thomas H. Buckley desenvolveu carroças coloridas preparadas especificamente para servir comidas, com ímãs, refrigeradores e fogões acoplados. Até os anos 2000 os food trucks possuíam o estigma de servir comida barata, de baixa qualidade, imagem que mudou com a crise econômica de 2008, quando a falência de vários restaurantes renomados propiciou investimentos de alguns chefs no antigo mercado de street food. No Brasil o movimento surgiu em 2012 em São Paulo e hoje os eventos de food truck já integram roteiros turísticos das grandes cidades (Aguiar, 2015 ) \& (Spinacé, 2014).

Em termos de infraestrutura, nos food trucks observa-se que "na parte da frente do veículo", logo abaixo do balcão onde os clientes

\section{INTRODUCTION}

The study of festivals and gastronomic events is one important area of Tourism, in which scientific production has presented significant growth in recent decades. Those events offer an ideal opportunity for tourists and locals to interact and live new gastronomic experiences (Bortnowska, Alberton, Marinho, 2012). This moment represents a rich and relevant cultural exchange for both sides.

Nowadays many events have taken place, especially in big cities, with food trucks, other vehicles and food stands. The vehicle itself had been turned into a theme: a food truck event. In those spaces, consumption of food and beverage from different menus is offered at a more attractive cost than in standard restaurants and food services in general. Those prices can be achieved due to the inherit characteristics of this food service concept, which involves simple physical structure.

It is believed that food trucks were brought to the market in 1872, in Providence, Rhode Island, United States. Walter Scott, a street vendor, served cakes and sandwiches for factory workers in need of fast and cheap food. These two specific factors turned these types of food into good options. Thomas $\mathrm{H}$. Buckley developed colorful wagons specially designed to food serving, including magnets and coupled refrigerators and stoves. Until the year 2000, food trucks were best known for serving cheap, low quality food. This image has been changing since the 2008 economic crisis. Some chefs invested in the old street market segment after the bankruptcy of various renowned restaurants. In Brazil, the movement arouses in 2012 in São Paulo and nowadays food truck events are part of the main itineraries in big cities (Aguiar, 2015 ) \& (Spinacé, 2014).

In terms of infrastructure, food trucks are quite simple. The refrigerators are located in the front part of the vehicle, just below the counter in which customers' orders are taken. The vehicle is equipped with a sink, a grill, an industrial oven and a frying pan in the rear. They usually have a power generator. On the top, there is an 80 to 300 -liter water tank. The dirty water from the sink goes to another compartment in which it remains stored. At the end of a working day, this compartment has to be drained. The gas cylinders including a system to avoid gas leakage are located under the workbench (Spinacé, 2014). 
fazem os pedidos, ficam as geladeiras. $\mathrm{Na}$ parte de trás, uma pia, uma chapa, um fogão industrial e uma fritadeira. Normalmente, eles também têm um gerador. Em cima do truck fica uma caixa-d'água, que pode ter cerca de 80 até 300 litros. A água suja que sai da pia vai para outro compartimento, onde permance armazenada. Ao fim de cada jornada de trabalho, esse compartimento precisa ser esvaziado. O gás é fornecido por dois botijões embaixo da bancada de trabalho, com um sistema para evitar vazamentos (Spinacé, 2014).

Após realização de levantamento bibliográfico percebeu-se uma escassez de pesquisas sobre o tema em questão, assim sendo o objetivo do trabalho foi caracterizar os food trucks presentes em eventos gastronômicos no município do Rio de Janeiro.

\section{METODOLOGIA}

O trabalho consistiu em uma pesquisa de campo, um estudo observacional realizado em cinco eventos gastronômicos de food trucks (identificados como A, B, C, D e E) realizados no município do Rio de Janeiro, entre os meses de janeiro e abril de 2016. Nesses eventos foram selecionadas aleatoriamente um total de 10 empresas do segmento street food, apresentando-se como food trucks, food bikes, carrocinhas, barraquinhas e carros.

Foram observadas características dessas empresas, segundo metodologia adaptada de Cortese et al. (2016), a partir de itens referentes ao tipo de cozinha e de cardápio, vínculo do veículo/barraquinha com algum restaurante fixo, realização de propaganda durante o evento, disponibilidade de mobiliário (mesas e cadeiras) para clientes, tipo de veículo, número médio de funcionários, formas de pagamento das refeições e opções de comida e bebida.

Além desses pontos, foi avaliada, de maneira elementar, a conformidade da apresentação dos funcionários segundo as Boas Práticas de Manipulação (BPM), de acordo com parâmetros definidos pela Resolução RDC n0216 da Agência Nacional de Vigilância Sanitária (Anvisa), Ministério da Saúde (Brasil, 2004).
According to Rocancio, Quicazán \& Cárdenas (2015), a negative point in the administration of these gastronomic events relies on the precarious manufacturing practices related to liquid and solid waste management, as well as production practices in inadequate conditions. The authors mentioned above state that the site itself increases the possibility of food contamination through particles in the air, as the sales take place in public areas, close to vehicular traffic. In this context, the nonrespect of good hygiene practices generate health hazards.

After researching the existing literature in this field, it was realized that little attention has been paid to this subject. In order to help minimize this gap, the aim of this work is consisted in characterizing food trucks in gastronomic events in the city of Rio de Janeiro.

\section{METHODOLOGY}

The methodology consisted in an observational field research, taken place in five food trucks present in gastronomic events (identified as A, B, C, D and E) held in the city of Rio de Janeiro between January and April 2016. Ten street food companies, including food trucks, food bikes, food stands and cars, were randomly selected.

According to Cortese at al (2016), the used methodology was adapted to observe some characteristics, such as: type of kitchen and menu, possible connection to standard restaurants, advertisement during the event, available furniture (tables and chairs) for clients, type of vehicle, average number of employees, forms of payment and food and beverage options.

Besides these points, the presentation of the employees was audited as well. The study analyzed this aspect according to the Brazilian Good Manufacturing Practices document in compliance with RDC Resolution number 216, Ministry of Health (Brasil, 2004). This has only been done in a superficial way, however. Further studies in this subject would be highly indicated.

RESULTS AND DISCUSSION

RESULTADOS 


\section{Caracterização geral dos veículos e barraquinhas em eventos gastronômicos.}

A figura 1 apresenta resultados quantitativos acerca de barraquinhas e tipos de veículos presentes nos cinco eventos gastronômicos avaliados onde foi possível verificar uma predominância de food trucks $(46,0 \%)$, seguidos das carrocinhas $(34,0 \%)$ e barraquinhas $(10,0 \%)$, provavelmente porque esses dois últimos têm custos mais baixos de montagem e manutenção, embora limitem consideravelmente as opções de cardápio em função da infraestrutura. Nenhuma das empresas avaliadas encontra-se ligada a restaurantes fixos.

Um pequeno número de empresas presentes nos eventos estudados realizou propaganda durante o evento $(4,0 \%)$, nesse caso apenas a abordagem direta do cliente, convidando-o para conhecer o cardápio. De acordo com Leite \& Fernandes (2005) a aplicação de estratégias de propaganda adequadas e que estejam de acordo com as possibilidades financeiras de um empreendimento certamente ajudarão uma empresa a tornar-se competitiva no mercado onde qual a mesma está atuando, ao possível sucesso e à liderança em vendas.

Já com relação ao número médio de funcionários foram observadas médias de 2,3, $3,1,3,2,2,6$ e 2,3 funcionários nos eventos A, B, C, D e E, respectivamente. Os pequenos números de funcionários observados em todos os eventos estudados podem ser justificados por fatores como a simplicidade de operações para esse tipo de empreendimento e, no caso dos food trucks, espaço físico limitado que tornaria desconfortável a presença de muitos trabalhadores.

Verificou-se que $40,0 \%$ dos veículos e barraquinhas disponibilizavam mesas e cadeiras para uma melhor acomodação dos consumidores, o que representa um gesto de hospitalidade para com a clientela. De acordo com Araújo, Gonçalves \& Matias (2014) nos ambientes de alimentos e bebidas pode ser observada a hospitalidade comercial, ou seja, atendimento que vai além do serviço esperado, porém superando as expectativas do cliente, estratégia importante para fidelizar o consumidor.

Assim sendo, admite-se que a hospitalidade está diretamente relacionada às necessidades
General Characterization of the vehicles and barraquinhas 1 in the five selected gastronomic events in the city of Rio de Janeiro

The figure 1 presents the quantitative results on stands and types of vehicles in the five gastronomic events. It was verified a predominance of the number of food trucks $(46,0 \%)$, followed by carrocinhas ${ }^{2}(34,0 \%)$ and stands $(10,0 \%)$. The reason why lies in the fact that the carrocinhas and stands have lower assembly and maintenance costs. As a result they limit the options in the menu due to their lack of infrastructure. None of the evaluated companies is linked to a standadrestaurant.

A small amount of companies advertised during the events $(4,0 \%)$. In this case advertisement was performed only through direct contact with the customer, inviting them to check the menu. According to Leite \& Fernandes (2005) the application of adequate advertising strategies, within the available budget, will help companies become properly competitive, be a success and the leader in sales.

With regard to the average number of employees, the averages 2,3, 3,1, 2,6 and 2,3 were observed in the events $A, B, C, D$ and $E$ respectively. The small amount of employees saw in the studied events are justified in terms of the simplicity of the operations held in this type of enterprise and, in the case of food trucks, the limited physical space would create an uncomfortable environment for a large number of workers.

It is worth to notice the applicability of the results, since the data obtained serve as a subsidy for other researchers who may use this material as a starting point for further evaluation and research as the literature on the topic is quite scarce. Through the typologies perception of the production point and sales of food in gastronomic events for the tourism sector, the direct connexion with the limitations and the variability of preparations offered in such events can be understood.

It was verified that $40 \%$ of the vehicles and stands offered tables and chairs to better accommodate their customers, which represents a gesture of hospitality to the

1 Carrocinha: A kind of stand with wheels, used to sell food, moves by human traction.

2 Barraquinhas: A type of fixed stand, assembled in an improvised manner . 
e desejos das pessoas, ao próprio desejo instintivo de "ser bem recebido". Em um evento ao ar livre, como é o caso daqueles estudados no presente trabalho, torna-e agradável para - cliente ter disponíveis mesas e cadeiras para realizar sua refeição de maneira mais confortável, ainda que essa seja apenas um fast food, uma refeição sem formalidades relacionadas ao serviço tradicional.

Sobre as possíveis formas de pagamento dos alimentos e das bebidas, $80,0 \%$ das empresas aceitava pagamentos em dinheiro e cartões, flexibilidade que pode representar mais uma comodidade para o cliente.

Com relação aos aspectos fundamentais de higiene na manipulação dos alimentos foi verificado um considerável índice de não conformidades na avaliação de condições mínimas de Boas Práticas no que tange à apresentação dos funcionários, pois em média de $40,0 \%$ dos veículos e barraquinhas observados não atendiam a requisitos mínimos de higiene.

Essas não conformidades eram referentes à ausência do uso de uniforme $(14,0 \%)$, uso de diversos adornos como anéis, brincos, cordões, piercings, pulseiras e relógios $(46,0 \%)$, barba $(32,0 \%)$, cabelos soltos e/ou sem proteção de toucas $(34,0 \%)$ e maquiagem $(14,0 \%)$.

Segundo Cortese et al. (2016), que realizaram pesquisa com vendedores ambulantes em Florianópolis/SC, os procedimentos de manipulação de alimentos dos trabalhadores do segmento de street food geralmente estão em desacordo com padrões de higiene.

Esse fato pode serconsiderado preocupante, pois coloca em risco a saúde do consumidor, pois este pode ingerir produtos contaminados, causadores de doenças transmitidas por alimentos (DTA). Especialmente no caso do município do Rio de Janeiro, famoso por suas temperaturas ambientais elevadas na maior parte do ano, os cuidados com a manipulação dos alimentos recebem destaque já que essa característica climática pode favorecer a proliferação microbiana.

\section{Perfis de cardápios}

Foi observada uma predominância de opções de alimentos em detrimento às opções de bebidas em todos os cinco eventos (Tabela 1). As bebidas incluíam clientele. According to Araújo, Gonçalves \& Matias (2014) in food and beverage environments commercial hospitality can be observed. Customer service goes beyond the expected service, but exceeding the customer's expectations that is an important strategy to ensure customer's loyalty.

Therefore, it is assumed that hospitality is directly related to people's needs and desires, to an instinctive desire of " being welcome ${ }^{3}$ ". In an open air event, that is in the case of the studied ones, tables and chairs are pleasant for the customers so they can have their meal in a more comfortable way, even though it is only a fast food meal without the related formalities of a traditional service.

About the available forms of payment, $80 \%$ of the companies accepted payment in cash and in credit cards. This flexibility represents one more convenience for the costumer.

In relation to the fundamental aspects of hygiene in the handling of food a considerable number of non-conformities were detected in the assessment of minimal conditions of Good Practice regarding the presentation of employees. Forty percent $(40 \%)$ of the vehicles and stands did not meet the minimal hygiene requirements.

These non-conformities referred to the absence of uniform $(14,0 \%)$, use of accessories, such as rings, earings, necklaces, piercings, bracelets and watches $(46,0 \%)$, beard $(32,0 \%)$, loosen hair or work without kitchen caps and wearing makeup $(14,0 \%)$.

According to Cortese et al. (2016) that conducted researches with street vendors in the city of Florianópolis in the state of Santa Catarina (Brazil), the handling procedures of food in the street food segment are usually not in compliance with high hygiene patterns.

This is a worrying fact because it can put at risk the costumer's health. He or she can ingest contaminated products that can cause diseases through food. In the city of Rio de Janeiro, with its high temperatures most months of the year, food handling procedures must be highlighted as this climate characteristic could help microbial growth.

Menu Profiles

The table 1 shows the average number of food options and beverage options in each of

3 Be welcomed by hosts. 
principalmente refrigerantes, águas e cervejas (principalmente artesanais), e também drinks e sucos.

A tabela 2 apresenta os resultados acerca dos tipos de cozinhas e cardápios dos eventos em questão onde foi possível verificar uma predominância de hambúrgueres (Cozinha Norte-americana) e outros tipos de sanduíches em todos os eventos estudados, fato que pode estar relacionado às raízes históricas dos food trucks, que segundo Aguiar (2015) \& Spinacé (2014) originalmente vendiam sanduíches para trabalhadores fabris. Além disso, cabe ressaltar que essas são preparações culinárias de alta aceitabilidade perante muitos consumidores. Veículos e carrocinhas de Cozinha Italiana (massas e pizzas variadas) também apresentaram-se como destaque, uma vez que estavam presentes em $80,0 \%$ dos eventos.

Itens da Cozinha Brasileira foram encontrados em apenas em 40,0\% dos eventos, nos quais estavam à venda preparações culinárias como acarajés, pão de queijo, tapiocas e petiscos típicos da comida de boteco carioca. Em termos turísticos, esses resultados podem ser considerados negativos visto que o Rio de Janeiro recebe um considerável número de turistas que possivelmente seriam atraídos para consumir outros pratos nacionais caso os mesmos estivessem disponíveis.

De acordo com Tsai \& Wang (2016) a vontade de conhecer alimentos produzidos no local da viagem tem impulsionado muitos turistas a incluir em seus roteiros certos restaurantes, além de visitas aos pequenos produtores alimentícios e eventos gastronômicos. Embora os food trucks tenham origem norte-americana, é interessante considerar que um maior número de opções de pratos da Cozinha Brasileira em eventos com esse tema pode fomentar o fortalecimento da cultura alimentar nacional; obviamente enfatizando itens da culinária local, como maneira de ressaltar a valorização da cultura alimentar nativa.

Outro fato a ser destacado é a presença de várias opções semivegetarianas e ovolactovegetarianas em todos os eventos, inclusive naqueles nos quais havia predominância de veículos e barraquinhas comercializando hambúrgueres e demais sanduíches. Empresas que trabalham com culinárias orientais (chinesa e japonesa), além daquelas com proposta fit (saudáveis) the five gastronomic events.

A predominance of the number of food options in detriment of the number of beverage options in the five events (Table 1 ). The beverage included mainly soft drinks, water and beers (mainly artisan ou homemade beer), and also drinks and juice.

The table 2 shows types of cuisines and menus in those events. It was possible to verify a predominance of burgers (North American cuisine) and other types of sandwiches in the studied events. This fact is possibbly related to the historical roots of food trucks that according to Aguiar (2015) and Spinacé (2014) originally sold burgers to factory workers. Besides, these are culinary preparations is highly accepted among most costumers. Vehicles and carrocinhas that sold Italian Cuisine (pasta and pizza) were also a highlight as they were in $80 \%$ of the events.

Items of Brazilian cuisine were found in only $40 \%$ of the events, including acarajés, pão de queijo, tapiocas and typical Rio de Janeiro's "comida de boteco"4.

In touristic terms, these results could be considered negative since Rio de Janeiro receives a considerable number of tourists that would be possibly willing to consume other national dishes, if available.

According to Tsai \& Wang (2016) the desire of being acquainted with food produced locally has driven many tourists to include certain restaurants in their itinerary, visit small alimentary producers and attend gastronomic events. Even though food trucks have North American origin, a larger number of Brazilian cuisine dishes in these events could promote the strengthening of the national food culture emphasizing the items of local cuisine as a way to stimulate the appreciation for the native food culture.

Another important fact resides in the various semi vegetarian and egg-lactovegeterians options found in all events, including those in which there were predominance of vehicles and stands selling burgers and other sandwiches. Companies specialized in Oriental (Chinese and Japanese) cuisines, besides the ones with fit (healthy) concept, represent options that attract the vegetarian costumer. This way, they could choose for fast food without putting aside

$4^{\text {IV }}$ COMIDA DE BOTECO : expression referring to typical food served in original Brazilian bars in the city of Rio de Janeiro. 
representam opções que despertam interessante do cliente vegetariano, que, dessa forma, pode optar pelo fast food sem deixar suas preferências e/ou crenças de lado.

Além disso, segundo Newson et al. (2015) existe na atualidade uma demanda por refeições mais saudáveis e com menores valores energéticos (ou seja, menos calóricas) em muitos serviços de alimentação em função do aumento de casos de sobrepeso obesidade. Desse modo, é compreensível que, assim como em restaurantes em geral e em setores de Alimentos e Bebidas de hotéis, em eventos gastronômicos também existiam opções de refeições saudáveis com vistas a atender uma demanda atual do consumidor.

Com relação ao perfil dessas preparações culinárias, Siebeneichler et al. (2007) destaca que tem sido verificados maiores números de opções nos cardápios, e estes têm ainda maior pluralidade em termos de pratos que contemplam itens de culinária regional, étnica, além de receitas estrangeiras. Cabe ressaltar que em função da área física disponível nos food trucks é compreensível a existência de poucas opções de comidas nos mesmos, e também um número restrito de funcionários.

\section{CONSIDERAÇÕES FINAIS}

Foi possível concluir que em encontros de food trucks há uma maior presença de caminhões tradicionais do que food bikes e carrocinhas; e percebeu-se como característica comum nesses eventos a baixa presença de propagandas, estas basicamente restritas aos banners dos veículos.

Outro fato a ser destacado é a presença de poucos funcionários com tarefas bem definidas, um em complemento do outro, sempre muito receptivos e comprometidos um atendimento de qualidade, baseado nos princípios da hospitalidade.

Sobre os perfis dos cardápios, houve predominância de itens da Cozinha Norte Americana, seguida da Italiana; e muitas opções de sanduíches diversos. Já as opções da Cozinha Brasileira não estavam presentes em todos os eventos, o que pode ser considerado um ponto que deve ser revisto considerando o aspecto turístico desse tipo de evento.

Um dos pontos a ser melhorado nesse tipo de comércio de alimentos e bebidas é o atendimento às Boas Práticas de Manipulação, visto que medidas simples de higiene their preferences or beliefs.

According to Newson et al. (2015) nowadays there is a demand for healthier and lower energy valued (i.e., less caloric) meals in several food services based on the increasing number of obese and overweight cases. As a consequence healthy meal options are also offered in food truck events as well as in restaurants in general and F\&B sectors in hotels to satisfy this ever-growing current demand.

In relation to the profile for these culinary preparations, Siebeneichler et al. (2007) emphasized the fact that there are more food options on the menus, and those have more plurality in terms of dishes that include regional ethics cuisine items, in addition to foreign recipes. According to the limited physical area available inside food trucks it is understandable that they offer few food options and have a restricted number of employees.

\section{CONCLUSION}

It was possible to conclude that in food truck events there are a larger number of traditional trucks rather than food bikes and carrocinhas. It was also noticed as a common characteristic of these events a low presence of advertisement. These were basically restricted to banners in the vehicles.

Other fact to be emphasized is the presence of few employees with well-defined tasks, one complementing the other. Those employees were always very receptive and compromised with a quality customer service, based on the hospitality principles.

About the menus' profiles, there was a predominance of the North American cuisine, followed by the Italian one. There were a lot of sandwich options as well. Brazilian cuisine options were not present in all events, which can be considered a point to be reconsidered due to the touristic aspect of this type of event.

The compliance with good manufacturing practices has to be emphasized since simple measures of hygiene were not carried out. It is worthwhile noting that even though the atmosphere is relaxed, designed for simple meals, everything and everyone must operate according to the Brazilian sanitary legislation. 
dos alimentos não foram atendidas. Cabe ressaltar que mesmo o ambiente sendo mais despojado, destinado à realização de refeições simples, é essencial que os profissionais envolvidos em eventos de food trucks atuem com concordância com a legislação sanitária brasileira.

\section{REFERÊNCIAS}

Aguiar, A. C. (2015). Food truck: saiba como surgiu essa moda. Revista Super Interessante. Acesso em:17/04/2016.

Araújo, R. M.; Gonçalves, S.; Matias, I. (2014) Hospitalidade comercial nos serviços de restauração: uma análise em Mossoró/RN. Cultur - Revista de Cultura e Turismo, ano 8, n.1, p.1-36.

Bortnowska, K.; Alberton, A.; Marinho, S. V. (2012) Cultura e alimentação: análise das festas gastronômicas na Serra Gaúcha. In: Anais do IX Seminário da Associação Nacional Pesquisa e Pós-Graduação em Turismo. São Paulo, SP.

Brasil. Ministério da Saúde. (2004). Agência Nacional de Vigilância Sanitária. Resolução RDC n²16, de 15 de setembro de 2004. Regulamento Técnico de Boas Práticas para Serviços de Alimentação. Diário Oficial da União

Cortese, R. D. M.; Veiros, M. B.; Feldman, C.; Cavalli, B. (2016). Food safety and hygiene practices of vendors during the chain of street food production in Florianopolis, Brazil: A cross-sectional study. Food Control, v.62, p.178-186.

Leite, A. P. R; Fernandes, L. O. (2005) A importancia do uso de estratégias de marketing para obter a vantagem competitiva em restaurantes: o caso do camarão potiguar. In: Anais do IV Simpósio de Excelência em Gestão e Tecnologia, p.1-15.

Newson, R. S.; Van derMaas, R.; Beijersbergen, A.; Carlson, L.; Rosenbloom, C. (2015) International consumer insights into the desires and barriers of diners in choosing healthy restaurant meals. Food Quality and Preference, v.43, p.63-70.

RONCANCIO, j. j. b.; QUICAZÁN, C. A. N.; CÁRDENAS, A. P. (2015) Iniciativas, ações e políticas sobre as vendas de alimentos na via pública. Cadernos Saúde Coletiva , v.23, p.17-24.

SIEBENEICHLER, t.; Wienningkamp, d.; Ruchel, a. p.; Trombini, e. s.; Zamberlan, I. (2007) A satisfação de clientes de restaurantes: uma avaliação da satisfação e da importância dos atributos. Revista de

\section{REFERENCES}

Aguiar, A. C. (2015). Food truck: saiba como surgiu essa moda. Revista Super Interessante. Acesso em:17/04/2016.

Araújo, R. M.; Gonçalves, S.; Matias, I. (2014) Hospitalidade comercial nos serviços de restauração: uma análise em Mossoró/RN. Cultur - Revista de Cultura e Turismo, ano 8, n.1, p.1-36.

Bortnowska, K.; Alberton, A.; Marinho, S. V. (2012) Cultura e alimentação: análise das festas gastronômicas na Serra Gaúcha. In: Anais do IX Seminário da Associação Nacional Pesquisa e Pós-Graduação em Turismo. São Paulo, SP.

Brasil. Ministério da Saúde. (2004). Agência Nacional de Vigilância Sanitária. Resolução RDC n²16, de 15 de setembro de 2004. Regulamento Técnico de Boas Práticas para Serviços de Alimentação. Diário Oficial da União

Cortese, R. D. M.; Veiros, M. B.; Feldman, C.; Cavalli, B. (2016). Food safety and hygiene practices of vendors during the chain of street food production in Florianopolis, Brazil: A cross-sectional study. Food Control, v.62, p.178-186.

Leite, A. P. R; Fernandes, L. O. (2005) A importancia do uso de estratégias de marketing para obter a vantagem competitiva em restaurantes: o caso do camarão potiguar. In: Anais do IV Simpósio de Excelência em Gestão e Tecnologia, p.1-15.

Newson, R. S.; Van der Maas, R.; Beijersbergen, A.; Carlson, L.; Rosenbloom, C. (2015) International consumer insights into the desires and barriers of diners in choosing healthy restaurant meals. Food Quality and Preference, v.43, p.63-70.

RONCANCIO, j. j. b.; QUICAZÁN, C. A. N.; CÁRDENAS, A. P. (2015) Iniciativas, ações e políticas sobre as vendas de alimentos na via pública. Cadernos Saúde Coletiva , v.23, p.17-24.

SIEBENEICHLER, t.; Wienningkamp, d.; Ruchel, a. p.; Trombini, e. s.; Zamberlan, I. (2007) A satisfação de clientes de restaurantes: uma avaliação da satisfação e da importância dos atributos. Revista de Administração, v.7, n.11 p.39-58.

Tsai, C.; Wang, Y. (2016) Experiential value in branding food tourism. Journal of Destination Marketing \& Management, in press.

Spinacé, N. (2014.) A invasão dos food trucks. Seção Gastronomia e Estilo. Revista Época, 
Administração, v.7, n.11 p.39-58.

Tsai, C.; Wang, Y. (2016) Experiential value in branding food tourism. Journal of Destination Marketing \& Management, in press.

Spinacé, N. (2014.) A invasão dos food trucks. Seção Gastronomia e Estilo. Revista Época,

\section{APÊNDICES E/OU ANEXOS - ATTACHMENTS}

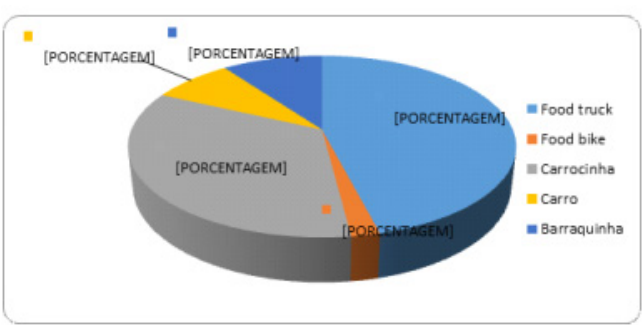

Figura 01 - Resultados quantitativos acerca de barraquinhas e tipos veículos presentes nos cinco eventos gastronômicos realizados no Rio de Janeiro/RJ.

Tabela 01 - Médias de opções de alimentos e bebidas em eventos de food truck realizados no município do Rio de Janeiro/RJ.

\begin{tabular}{|c|c|c|}
\hline Evento & Alimentos & Bebidas \\
\hline A & 3,9 & 2,2 \\
B & 7,2 & 0,3 \\
C & 5,1 & 1,4 \\
D & 6,6 & 1,3 \\
E & 7,1 & 1,3 \\
\hline
\end{tabular}

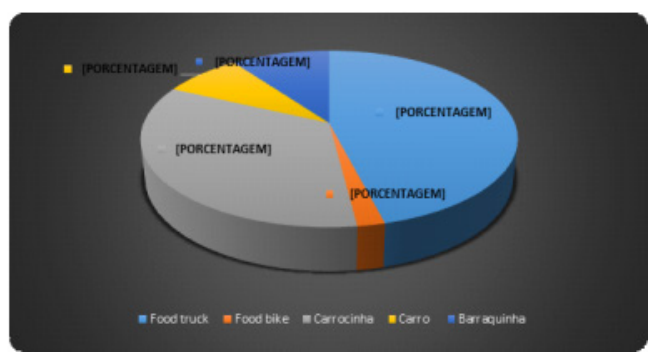

Figure 1: Quantitative results on stands and types of vehicles in the five selected gastronomic events in the city of Rio de Janeiro.

Table 1: Average number of food and beverage options in each of the five food truck events held in the city of Rio de Janeiro, RJ, Brazil.

\begin{tabular}{|c|c|c|}
\hline Event & Foods & Beverages \\
\hline A & 3,9 & 2,2 \\
B & 7,2 & 0,3 \\
C & 5,1 & 1,4 \\
D & 6,6 & 1,3 \\
E & 7,1 & 1,3 \\
\hline
\end{tabular}


Tabela 02 - Caracterização dos tipos de cozinhas e cardápios observados em eventos de food truck realizados no município do Rio de Janeiro/RJ.

\begin{tabular}{|c|c|c|}
\hline Evento & Tipos de cozinhas & Tipos de cardápios \\
\hline$A$ & $\begin{array}{c}\text { Italiana, russa e norte- } \\
\text { americana }\end{array}$ & $\begin{array}{c}\text { Pizzas, hambúrgueres (bovino, suíno, costela, vegetariano), } \\
\text { outros sanduíches (linguiça, filé de frango, filé de carne) } \\
\text { servidos em pão sírio ou baguete, estrogonofe (carne, frango, } \\
\text { camarão) }\end{array}$ \\
\hline$B$ & $\begin{array}{l}\text { Italiana, brasileira (mineira, } \\
\text { nordestina), norte-americana, } \\
\text { russa, (chinesa e japonesa) }\end{array}$ & $\begin{array}{c}\text { Massas em geral, pão de queijo, hambúrgueres (bovino e } \\
\text { suíno), tapiocas, sanduíche (costela, cachorro quente, pão de } \\
\text { queijo), batatas fritas, estrogonofe (carne, frango, camarão), } \\
\text { suhis, sahimis, konis, harumakis, yakissobas (sabores } \\
\text { variados) }\end{array}$ \\
\hline C & $\begin{array}{c}\text { Italiana, norte-americana, fit, } \\
\text { doçaria, sorveteria, brasileira } \\
\text { (carioca) }\end{array}$ & $\begin{array}{l}\text { Massas em geral, pizzas, hambúrgueres (bovino, salmão e } \\
\text { suíno), sanduíches (cachorro quente, pernil, vegetarianos), } \\
\text { saladas, churros, sorvetes, petiscos de boteco, batatas fritas }\end{array}$ \\
\hline D & $\begin{array}{c}\text { Alemã, norte-americana, } \\
\text { italiana, fit, venezuelana, } \\
\text { brasileira (bahiana), francesa }\end{array}$ & $\begin{array}{l}\text { Salsichões, hambúrgueres (bovino, salmão e suíno), batatas } \\
\text { fritas, nhoque, pratos vegetarianos, sanduíches (linguiça, filé } \\
\text { de frango, filé de carne), arepas, acarajé, crepes }\end{array}$ \\
\hline E & $\begin{array}{l}\text { Norte-americana, mexicana, } \\
\text { oriental (árabe, chinesa e } \\
\text { japonesa), fit }\end{array}$ & $\begin{array}{c}\text { Hambúrgueres (bovino, costela, salmão e suíno), tortillas, } \\
\text { burritos, tacos, nachos, suhis, sahimis, konis, harumakis, } \\
\text { yakissobas (sabores variados), espetos, batatas fritas, pratos } \\
\text { vegetarianos, sanduíches (linguiça, filés de frango, filé de } \\
\text { carne) }\end{array}$ \\
\hline
\end{tabular}

Table 2: Characterization of types of cuisine and menus in each of the food truck events held in the city of Rio de Janeiro, RJ, Brazil.

\begin{tabular}{|c|c|c|}
\hline EVENT & TYPES OF CUISINE & TYPES OF MENUS \\
\hline A & $\begin{array}{c}\text { Italian, Russian and North- } \\
\text { American }\end{array}$ & $\begin{array}{c}\text { Pizzas, hambúrgueres (beef, pork, ribs, vegetarian ) Other } \\
\text { sandwiches ( sausage, chicken fillet, beef fillet ) served in pita } \\
\text { bread or baguette, stroganoff ( beef, chicken, shrimp) }\end{array}$ \\
\hline B & $\begin{array}{l}\text { Italian, Brasilian (from the } \\
\text { state of Minas Gerais and } \\
\text { northeast region), American } \\
\text {, Russian, (Chinese and } \\
\text { Japanese) }\end{array}$ & $\begin{array}{l}\text { Several types of pasta, cheese bread (tipical from the state } \\
\text { of Minas Gerais, tapioca ( typical from Northeast of Brazil) } \\
\text {, burgers (beef and pork ) sandwich ( ribs, hot dogs, cheese } \\
\text { bread ), fries, stroganoff ( beef, chicken, shrimp), sushis, } \\
\text { sahimis, Konis, harumakis, yakissobas (varied flavors) }\end{array}$ \\
\hline C & $\begin{array}{c}\text { Italian, North -American, fit, } \\
\text { candys, ice cream parlor, Brazil } \\
\text { ( Rio de Janeiro ) }\end{array}$ & $\begin{array}{c}\text { Pastas in general , pizzas, burgers (beef, salmon and pork), } \\
\text { sandwiches (hot dogs, ham, vegetarian), salad, churros, ice } \\
\text { cream, pub snacks, chips. }\end{array}$ \\
\hline D & $\begin{array}{l}\text { German , American , Italian } \\
\text {, fit , Venezuelan , Brazilian } \\
\text { (from the state of Bahia ), } \\
\text { French }\end{array}$ & $\begin{array}{c}\text { Sausages, burgers ( beef, salmon and pork ), French fries, } \\
\text { gnocchi, vegetarian dishes, sandwiches ( sausage, chicken } \\
\text { fillet, fillet of beef ), arepas, acarajé (typical from state of } \\
\text { Bahia ), crepe }\end{array}$ \\
\hline E & $\begin{array}{l}\text { North American, Mexican, } \\
\text { Eastern (Arabic, Chinese and } \\
\text { Japanese ), fit }\end{array}$ & $\begin{array}{c}\text { Burgers ( beef, ribs, salmon and pork ), tortillas, burritos, } \\
\text { tacos, nachos, sushis, sahimis, Konis, harumakis, yakissobas } \\
\text { ( varied flavors ), skewers, fries, vegetarian dishes, } \\
\text { sandwiches (sausage, chicken fillets, fillet meat) }\end{array}$ \\
\hline
\end{tabular}

